Prider $\mathrm{SCIDOC}$

International Journal of Diabetology \& Vascular Disease Research (IJDVR)

ISSN:2328-353X

\title{
Total Adiponectin and Risk of Symptomatic Lower Extremity Peripheral Vascular Disease in Type 2 Diabetes Mellitus
}

Research Article

Kumar $\mathrm{S}^{*}$, Gupta $\mathrm{AK}^{2}$, Chandrashekhar $\mathrm{B}^{3}$

${ }^{1}$ Professor, Department of Medicine, SPMC, Bikaner, Rajasthan, India.

${ }^{2}$ Senior Resident, Department of Medicine, SPMC, Bikaner, Rajasthan, India.

${ }^{3} 2^{\text {nd }}$ year PG Student, Department of Medicine, SPMC, Bikaner, Rajasthan, India.

\section{Abstract}

Objective: Adiponectin is an adipocyte-derived protein that has gained considerable research interest because of its pleiotropic effects on insulin sensitivity, atherosclerosis and inflammation. Lower concentrations of adiponectin have been linked to subsequent risk of coronary heart disease in healthy individuals. Whether similar relationships exist for the development of systemic atherosclerosis, such as peripheral vascular disease (PVD), is uncertain. We investigated the association between total adiponectin and risk of lower extremity PVD.

Methods and Results: We performed a case control study among 60 diabetic patients in tertiary center, PBM Hospital, bikaner, who were free of diagnosed cardiovascular disease. Among 60 patients, 6 developed PVD. Using risk set sampling, controls were selected and matched on age, no smoking status, fasting status, lipid profile, HbA1c, RFT and BMI. On distributing cases according to Adiponectin level in Relation to PVD, total of 60 patients were included in study and distributed in two groups of either decreased or normal adiponectin level. A total of 6 patients had PVD of which adiponectin levels were decreased in 5 patients and normal in 1, and on application of test of significance they were found to be statistically significant with $\mathrm{p}$ value of 0.01

Conclusion: Total adiponectin is inversely associated with risk of symptomatic lower extremity PVD in diabetes patients.

Keywords: Adiponectin; Peripheral Vascular Disease; Diabetes Mellitus; Atherosclerosis.

Abbreviations: PVD: Peripheral Vascular Disease; CVD: Cardiovascular Disease; HDL: High-Density Lipoprotein; MI: Myocardial Infarction; TNF- $\alpha$ : Tumor Necrosis Factor Alpha; NF- $\varkappa$ B: Nuclear Factor Kappa B.

\section{Introduction}

Adiponectin is an adipocyte-derived protein that has gained considerable research interest because of its pleiotropic effects on insulin sensitivity, atherosclerosis and inflammation [1]. In addition to a consistently lower risk of type 2 diabetes [2], higher adiponectin concentrations have also been associated with lower risk of cardiovascular disease (CVD) in several studies [3-5]. More recent epidemiological reports, however, observed weaker inverse associations [4, 6] after adjustment for high-density lipoprotein (HDL) cholesterol [7-9], questioning the putatively protective and independent role of adiponectin in atherosclerotic diseases.
Peripheral vascular disease (PVD) is a manifestation of systemic atherosclerosis that affects an estimated 10 million U.S. adults and is associated with reduced functional capacity [10] and increased risk for cardiovascular morbidity and mortality $[12,13]$. Although cholesterol and inflammatory risk factors are also strong predictors in this form of CVD [14, 15], PVD is characterized by progressive luminal obstruction in peripheral arteries and may be less related to thrombosis or plaque rupture than are myocardial infarction (MI) or ischemic stroke $[16,17]$. This raises the possibility that factors with anti-atherosclerotic and antiinflammatory properties, like adiponectin, may be of particular importance in the development of this type of CVD.

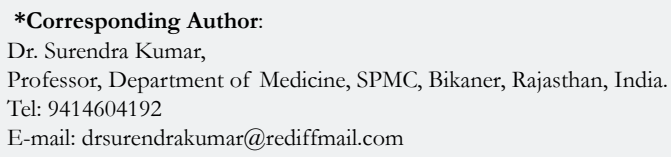

Copyright: Kumar $\mathbf{S}^{\circ}$ 2019. This is an open-access article distributed under the terms of the Creative Commons Attribution License, which permits unrestricted use, distribution and reproduction in any medium, provided the original author and source are credited. 
To evaluate the association of total adiponectin with risk of PVD in the lower extremities, we studied diabetes patients in tertiary care center.

\section{Method and Results}

We performed a case control study among 60 diabetic patients in tertiary center, PBM Hospital, bikaner, who were free of diagnosed cardiovascular disease. Among 60 patients, 6 developed PVD. Using risk set sampling, controls were selected and matched on age, no smoking status, fasting status, lipid profile, HbA1c, RFT and BMI. We found a strong inverse association between total adiponectin and risk of lower extremity PVD in otherwise healthy patients. On distributing cases according to Adiponectin level in Relation to PVD, total of 60 patients were included in study and distributed in two groups of either decreased or normal adiponectin level.

Baseline characteristics of cases and controls are presented in table 1 . Both case and control are matchable in all background characteristics.

As shown in table 2, out of 60 cases 6 patients had PVD. So the prevalence of PVD in our study was found to be $10 \%$.

Table 3 shows distribution of cases According to Age Group in Relation to PVD. Out of total of 60 patients, 1 patient fall under the age group of $<40$ years while 7 and 18 patients belongs to age group of 41-50 and 51-60 age group respectively, 23 patients had their age between 61-70 years while 11 patients were of $71-80$ years age group.

In present study total 6 patients had their PVD positive and out of them 1, 1 and 4 were belonged to age group less than $<40,51$ 60 and $61-70$ years respectively and this relation was found to be statistically significant.

Table 4 shows distribution of cases According to Sex in Relation to PVD, out of 60 patients, 6 had PVD and among them 3 were males and 3 were females, On applying chi square test, the difference was found to be statistically insignificant $(p=0.86)$.

Table 5 shows Distribution of cases According to ABI in Relation to PVD. 10 percent of patient had severe as well as abnormal value of $\mathrm{ABI}$ with none of the patient falling in severely diseased, while 80 percent of patients had normal ABI.

Table 6 shows distribution of cases according to adiponectin level in Relation to PVD, total of 60 patients were included in study and distributed in two groups of either decreased or normal adiponectin level, a total of 6 patients had PVD of which adiponectin levels were decreased in 5 patients and normal in 1, and on application of test of significance they were found to be statistically significant with $\mathrm{p}$ value of 0.01 . The same findings are represented graphically in graph 1 .

\section{Discussion}

In this study, we found a strong inverse association between total adiponectin and risk of lower extremity PAD in otherwise healthy patients, on distributing cases according to Adiponectin level in Relation to PVD, total of 60 patients were included in study and distributed in two groups of either decreased or normal adiponectin level, a total of 6 patients had PVD of which adiponectin levels were decreased in 5 patients and normal in 1 , and on application of test of significance they were found to be statistically significant with $\mathrm{p}$ value of 0.01 .

To our knowledge, only one prospective study has investigated the effect of adiponectin on risk of incident PAD [18]. Several potential mechanisms could explain the lower risk of PAD associated with higher adiponectin concentrations. Adiponectin may suppress smooth muscle cell proliferation and foam cell formation of macrophages and inhibit monocytic cell adhesion to endothelial cells. It may suppress inflammatory pathways in endothelial cells through down regulation of the nuclear factor

Table 1. Baseline characteristics of cases and controls.

\begin{tabular}{|c|c|c|}
\hline Characteristics & Cases (n=6) & Control (n=54) \\
\hline Age & 58.33 & 61.29 \\
\hline Smoking & Nil & Nil \\
\hline Alcohol & Nil & Nil \\
\hline Lipid profile & Normal & Normal \\
\hline $\mathrm{Hb}_{\mathrm{A} 1 \mathrm{c}}$ & 8.4 & 8.1 \\
\hline $\mathrm{RFT}$ & Normal & Normal \\
\hline $\mathrm{CRP}$ & Negative & Negative \\
\hline $\mathrm{BMI}$ & 24.8 & 24.6 \\
\hline Physical activity & Moderate & Moderate \\
\hline Cardiovascular disease & None & None \\
\hline
\end{tabular}

Table 2. Prevalence of PVD $(\mathrm{ABI}<0.90)$.

\begin{tabular}{|c|c|c|}
\hline Prevalence of PVD & Number of cases & $\mathbf{\%}$ \\
\hline Total number of cases & 60 & 100 \\
\hline PVD cases & 6 & 10 \\
\hline
\end{tabular}


Table 3. Distribution of cases According to Age Group in Relation to PVD.

\begin{tabular}{|c|c|c|c|c|c|}
\hline \multirow{2}{*}{ Age Group } & \multicolumn{2}{|c|}{ PVD Present } & \multicolumn{2}{|c|}{ PVD Absent } & \multirow{2}{*}{ Total } \\
\cline { 2 - 5 } & NO & $\mathbf{\%}$ & NO & $\mathbf{\%}$ & \\
\hline$<40$ & 1 & 16.67 & 0 & 0.00 & 1 \\
\hline $41-50$ & 0 & 0.00 & 7 & 12.9 & 7 \\
\hline $51-60$ & 1 & 16.67 & 17 & 31.48 & 18 \\
\hline $61-70$ & 4 & 66.67 & 19 & 35.19 & 23 \\
\hline $71-80$ & 0 & 0.00 & 11 & 20.3 & 11 \\
\hline Total & 6 & \multicolumn{5}{|c|}{54} & & 60 \\
\hline Mean $=12$ (Positive $=1.2 ;$ Negative $=10.8$ ) \\
S.D. = 21.16 (Positive $=2.68 ;$ Negative $=18.73$ ) \\
\hline
\end{tabular}

Chi Square - 12.79, p value - 0.01

Table 4. Distribution of cases According to Sex in Relation to PVD.

\begin{tabular}{|c|c|c|c|c|c|}
\hline \multirow{2}{*}{ Sex } & \multicolumn{2}{|c|}{ PVD Present } & \multicolumn{2}{c|}{ PVD Absent } & Total \\
\cline { 2 - 6 } & NO & $\mathbf{0}$ & NO & $\mathbf{\%}$ & \\
\hline Male & 3 & 50 & 25 & 46.30 & 28 \\
\hline Female & 3 & 50 & 29 & 53.70 & 32 \\
\hline Total & 6 & & 54 & & 60 \\
\hline
\end{tabular}

Chi Square - 0.029, p value - 0.86

Table 5. Distribution of cases According to ABI.

\begin{tabular}{|c|c|c|}
\hline \multirow{2}{*}{ ABI } & \multicolumn{2}{|c|}{ Cases } \\
\cline { 2 - 3 } & No. & $\mathbf{\%}$ \\
\hline Critical $(<0.5)$ & 0 & 0 \\
\hline Severe $(0.5-0.9)$ & 6 & 10 \\
\hline Abnormal $(<0.91-1)$ & 6 & 10 \\
\hline Normal $(>1)$ & 48 & 80 \\
\hline
\end{tabular}

Table 6. Distribution of cases According to Adiponectin level in Relation to PVD.

\begin{tabular}{|c|c|c|c|c|c|}
\hline \multirow{2}{*}{ Adiponectin Level } & \multicolumn{4}{|c|}{ PVD } & \multirow{3}{*}{ Total } \\
\cline { 2 - 5 } & \multicolumn{2}{|c|}{ Present } & \multicolumn{2}{|c|}{ Absent } & \\
\cline { 2 - 5 } & No & $\mathbf{\%}$ & No & $\mathbf{\%}$ & \\
\hline Decrease & 5 & 83.33 & 26 & 48.15 & 31 \\
\hline Normal & 1 & 16.67 & 28 & 51.85 & 29 \\
\hline Total & 6 & & 54 & & 60 \\
\hline
\end{tabular}

Chi Square - 12.57, p value - 0.01

kappa B $(\mathrm{NF}-\kappa \mathrm{B})$ pathway, a key regulator in tumor necrosis factor alpha (TNF- $\alpha)$ and other cytokines [19]. Adiponectin also reduces the development of atherosclerosis in mice prone to its development [20], whereas in humans, low adiponectin may predict coronary artery disease severity and progression [21, 22]. Also, adiponectin may lower the risk of atherosclerosis through its effect on insulin sensitivity [23], and subsequently lower risk of type 2 diabetes.

Although compelling experimental evidence suggests a protective role of adiponectin in atherosclerosis, prospective data on adiponectin and risk of forms of CVD other than PAD seem less consistent. There are a number of possible explanations for this discrepancy. First, heterogeneity in case definitions may play a role: combining atherosclerotic events inversely related to adiponectin with other cardiovascular outcomes less immediately related to atherosclerosis, such as heart failure and fatal CVD (including sudden cardiac death). Second, the discrepancy may relate to the paradoxically increased risk of all-cause and CVD mortality associated with adiponectin mostly observed among older adults 


\section{Graph 1. Distribution of cases According to Adiponectin level in Relation to PVD.}

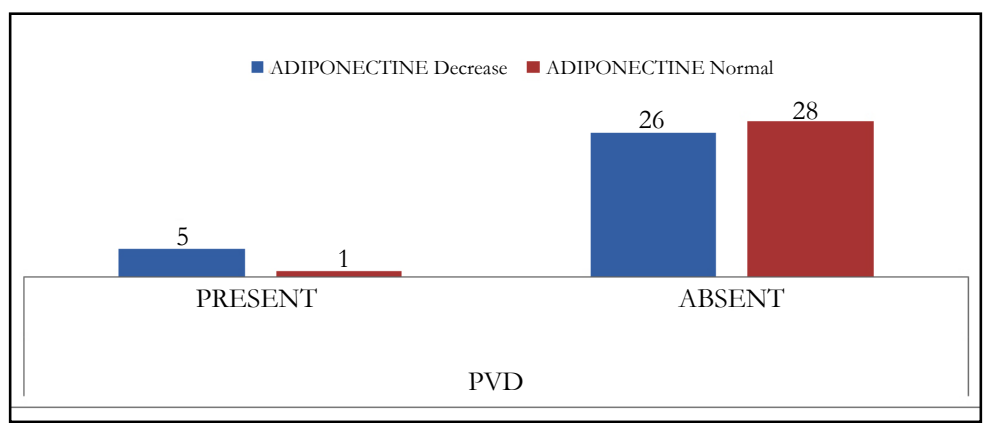

[24-26] and patients with prevalent heart failure [27], CVD [28, 29], PAD [30] or on hemodialysis [28] but also among apparently healthy men free of coronary artery disease [29]. Adiponectin has pleiotropic roles beyond its known insulin-sensitizing actions, including clearance of apoptotic cells [29]. As a result, it may directly improve insulin sensitivity and endothelial function even as levels rise in response to ongoing processes that lead to cellular apoptosis and necrosis and presumably mortality. In conclusion, we observed a strong linear inverse association between total adiponectin and risk of symptomatic lower extremity PAD in men free of manifest atherosclerotic disease. The association appeared to be independent of important biochemical or traditional clinical risk factors of CVD. These findings suggest a prominent role of adiponectin in the initiation and progression of atherosclerotic diseases such as PAD. Future mechanistic studies and prospective studies with well-characterized individuals are warranted to better understand the role of adiponectin in atherosclerosis.

\section{Conclusion}

Total adiponectin is inversely associated with risk of symptomatic lower extremity PVD in diabetes patients.

\section{References}

[1]. Heiker JT, Kosel D, Beck-Sickinger AG. Molecular mechanisms of signal transduction via adiponectin and adiponectin receptors. Biol Chem. 2010 Sep;391(9):1005-18. doi: 10.1515/BC.2010.104. PubMed PMID: 20536390.

[2]. Simpson F, Whitehead JP. Adiponectin--it's all about the modifications. Int J Biochem Cell Biol. 2010 Jun;42(6):785-8. doi: 10.1016/j.biocel.2009.12.021. PubMed PMID: 20044026.

[3]. Sheng T, Yang K. Adiponectin and its association with insulin resistance and type 2 diabetes. J Genet Genomics. 2008 Jun;35(6):321-6. doi: 10.1016/ S1673-8527(08)60047-8. PubMed PMID: 18571119.

[4]. Fagerberg B, Kellis D, Bergström G, Behre CJ. Adiponectin in relation to insulin sensitivity and insulin secretion in the development of type 2 diabetes: a prospective study in 64-year-old women. J Intern Med. 2011 Jun;269(6):636-43. doi: 10.1111/j.1365-2796.2010.02336.x. PubMed PMID: 21198995

[5]. Arita Y, Kihara S, Ouchi N, Takahashi M, Maeda K, Miyagawa JI, et al. Paradoxical decrease of an adipose-specific protein, adiponectin, in obesity. Biochem Biophys Res Commun. 1999 Apr 2;257(1):79-83. PubMed PMID: 10092513.

[6]. Han SH, Sakuma I, Shin EK, Koh KK. Antiatherosclerotic and anti-insulin resistance effects of adiponectin: basic and clinical studies. Prog Cardiovasc Dis. 2009 Sep-Oct;52(2):126-40. doi: 10.1016/j.pcad.2009.06.004. PubMed PMID: 19732605.

[7]. Strojek K, Ziora D, Sroczynski JW, Oklek K. Pulmonary complications of type 1 (insulin-dependent) diabetic patients. Diabetologia. 1992 Dec;35(12):1173-6. PubMed PMID: 1478371.

[8]. Innocenti F, Fabbri A, Anichini R, Tuci S, Pettina G, Vannucci F, et al. Indications of reduced pulmonary function in type 1 (insulin-dependent) diabetes mellitus. Diabetes Res Clin Pract. 1994 Oct;25(3):161-8. PubMed
PMID: 7851270

[9]. Asanuma Y, Fujiya S, Ide H, Agishi Y. Characteristics of pulmonary function in patients with diabetes mellitus. Diabetes Res Clin Pract. 1985 Aug;1(2):95-101. PubMed PMID: 3836101.

[10]. Mori H, Okubo M, Okamura M, Yamane K, Kado S, Egusa G, et al. Abnormalities of pulmonary function in patients with non-insulin-dependent diabetes mellitus. Intern Med. 1992 Feb;31(2):189-93. PubMed PMID: 1600265 .

[11]. Ljubić S, Metelko Ž, Car N, Roglić G, Dražić Z. Reduction of diffusion capacity for carbon monoxide in diabetic patients. Chest. 1998 Oct;114(4):1033-5. PubMed PMID: 9792573.

[12]. Matsubara T, Hara F. The pulmonary function and histopathological studies of the lung in diabetes mellitus. Nihon Ika Daigaku Zasshi. 1991 Oct;58(5):528-36. PubMed PMID: 1744225.

[13]. Fuso L, Cotroneo P, Basso S, De Rosa M, Manto A, Ghirlanda G, et al. Postural variations of pulmonary diffusing capacity in insulin-dependent diabetes mellitus. Chest. 1996 Oct 1;110(4):1009-13. PubMed PMID: 8874261.

[14]. Seidell JC, Kahn HS, Williamson DF, Lissner L, Valdez R. Report from a Centers for Disease Control and Prevention Workshop on use of adult anthropometry for public health and primary health care. Am J Clin Nutr. 2001 Jan;73(1):123-6. PubMed PMID: 11124761.

[15]. Stevens J, Couper D, Pankow J, Folsom AR, Duncan BB, Nieto FJ, et al. Sensitivity and specificity of anthropometrics for the prediction of diabetes in a biracial cohort. Obes Res. 2001 Nov;9(11):696-705. PubMed PMID: 11707536.

[16]. Ouchi N, Kihara S, Arita Y, Okamoto Y, Maeda K, Kuriyama H, et al. Adiponectin, an adipocyte-derived plasma protein, inhibits endothelial nfkappab signaling through a camp-dependent pathway. Circulation. 2000 Sep 12;102(11):1296-301. PubMed PMID: 10982546.

[17]. Okamoto Y, Kihara S, Ouchi N, Nishida M, Arita Y, Kumada M, et al. Adiponectin reduces atherosclerosis in apolipoprotein E-deficient mice. Circulation. 2002 Nov 26;106(22):2767-70. PubMed PMID: 12451000.

[18]. von Eynatten M, Schneider JG, Humpert PM, Kreuzer J, Kuecherer H, Katus HA, et al. Serum adiponectin levels are an independent predictor of the extent of coronary artery disease in men. J Am Coll Cardiol. 2006 May 16;47(10):2124-6. PubMed PMID: 16697337.

[19]. Maahs DM, Ogden LG, Kinney GL, Wadwa P, Snell-Bergeon JK, Dabelea $\mathrm{D}$, et al. Low plasma adiponectin levels predict progression of coronary artery calcification. Circulation. 2005 Feb 15;111(6):747-53. PubMed PMID: 15699257.

[20]. Lawlor DA, Davey Smith G, Ebrahim S, Thompson C, Sattar N. Plasma adiponectin levels are associated with insulin resistance, but do not predict future risk of coronary heart disease in women. J Clin Endocrinol Metab. 2005 Oct;90(10):5677-83. PubMed PMID: 16076942.

[21]. Wannamethee SG, Whincup PH, Lennon L, Sattar N. Circulating adiponectin levels and mortality in elderly men with and without cardiovascular disease and heart failure. Arch Intern Med. 2007 Jul 23;167(14):1510-7. PubMed PMID: 17646605.

[22]. Kizer JR, Barzilay JI, Kuller LH, Gottdiener JS. Adiponectin and risk of coronary heart disease in older men and women. J Clin Endocrinol Metab. 2008 Sep;93(9):3357-64. doi: 10.1210/jc.2008-0640. PubMed PMID: 18593765.

[23]. Kizer JR, Benkeser D, Arnold AM, Mukamal KJ, Ix JH, Zieman SJ, et al. Associations of total and high-molecular-weight adiponectin with all-cause and cardiovascular mortality in older persons: the Cardiovascular Health Study. Circulation. 2012 Dec 18;126(25):2951-61. doi: 10.1161/CIRCULATIONAHA.112.135202. PubMed PMID: 23159554.

[24]. Kistorp C, Faber J, Galatius S, Gustafsson F, Frystyk J, Flyvbjerg A, et al. Plasma adiponectin, body mass index, and mortality in patients with 
chronic heart failure. Circulation. 2005 Sep 20;112(12):1756-62. PubMed PMID: 16157772.

[25]. Dekker JM, Funahashi T, Nijpels G, Pilz S, Stehouwer CD, Snijder MB, et al. Prognostic value of adiponectin for cardiovascular disease and mortality. J Clin Endocrinol Metab. 2008 Apr;93(4):1489-96. doi: 10.1210/jc.20071436. PubMed PMID: 18211973

[26]. Hascoet S, Elbaz M, Bongard V, Bouisset F, Verdier C, Vindis C, et al. Adiponectin and long-term mortality in coronary artery disease participants and controls. Arterioscler Thromb Vasc Biol. 2013 Jan;33(1):e19-29. doi: 10.1161/ATVBAHA.112.300079. PubMed PMID: 23139295.

[27]. Dieplinger B, Haltmayer M, Poelz W, Mueller T. Value of adiponectin as predictor of 5 -year all-cause mortality in patients with symptomatic pe- ripheral arterial disease: results from the Linz Peripheral Arterial Disease (LIPAD) study. Clin Chim Acta. 2009 Oct;408(1-2):87-91. doi: 10.1016/j. cca.2009.07.014. PubMed PMID: 19646980.

[28]. Menon V, Li L, Wang X, Greene T, Balakrishnan V, Madero M, et al. Adiponectin and mortality in patients with chronic kidney disease. J Am Soc Nephrol. 2006 Sep;17(9):2599-606. PubMed PMID: 16885405.

[29]. Fraser DA, Tenner AJ. Directing an appropriate immune response: the role of defense collagens and other soluble pattern recognition molecules. Curr Drug Targets. 2008 Feb;9(2):113-22. PubMed PMID: 18288962.

[30]. Genovese E, Brigham CR, American Medical Association Staff. Guides to the evaluation of permanent impairment. American Medical Association; 2007. 